\title{
EFFECT OF SOLANUM TRILOBATUM LINN ON MERCURY-INDUCED HEPATOTOXICITY IN SWISS ALBINO MICE
}

\author{
*Manivannan Ekambaram ${ }^{1}$, Kothai Arul Ramalingam ${ }^{2}$, Arul Balasubramanian² \\ ${ }^{1}$ Department of Pharmacology, Vinayaka Mission's Kirupanandha Variyar Medical College and Hospital, Seeragapadi Salem-636 308 , \\ Tamilnadu, India \\ ${ }^{2}$ Vinayaka Mission's College of Pharmacy, Salem, Tamilnadu, India \\ *Corresponding Author's Email: emanivannan@yahoo.co.in
}

Received 07 Oct 2012; Review Completed 19 Oct 2012; Accepted 01 Nov 2012, Available online 15 Nov 2012

\begin{abstract}
Solanum trilobatum Linn. has been evaluated for its hepatoprotective activity in Swiss albino mice using the mercury induced hepatotoxicity. The chloroform extract showed remarkable activity against mercury-induced hepatotoxicity as judged from biochemical parameters such as serum aspartate amino transferase (AST), alanine amino transferase (ALT), alkaline phosphatase (ALP) and levels of lipid peroxides (LPO) in liver. Animals treated with S. trilobatum extract before and after mercury intoxication showed a significant decrease in LPO level, AST and ALT activities and increase in ALP activity and glutathione (GSH) content. The extract treatment alone did not alter the biochemical parameters. The results suggest that oral administration of $S$. trilibatum provide protection against mercury induced toxicity in Swiss albino mice, but it was dose dependent, which was comparable to the control.
\end{abstract}

Keywords: Chloroform extract; Solanum trilobatum; mercury induced; anti-hepatotoxic;

\section{INTRODUCTION}

Mercury is a transition metal; it promotes the formation of reactive oxygen species (ROS) such as hydrogen peroxides. These ROS enhances the subsequent iron and copper-induced production of lipid peroxides and the highly reactive hydroxyl radical ${ }^{1-3}$. These lipid peroxides and hydroxyl radical may cause the cell membrane damage and thus destroy the cell. Mercury also inhibits the activities of the free radical quenching enzymes catalase, superoxide dismutase and glutathione peroxidase ${ }^{4}$. Exposure to mercury cannot be avoided since it is being widely used in the industrial, medical, agriculture and other fields. Thus it is important to develop an effective drug to provide protection against mercury-induced toxicity. Several naturally occurring dietary and non-dietary constituents and parts of several species of edible plants having pharmacological activity, influence the antioxidant enzymes and provide protection against free radical induced damage.

Solanum trilobatum Linn. (Solanaceae) is a small plant widely distributed throughout India. The roots and leaves are bitter and prescribed in consumptive cases in the form of electuary, decoction and powder. A decoction of the entire plant 1 in 10 was administered to cases of acute and chronic bronchitis and found to be useful in those diseases. This is considered to be a home remedy for all kinds of $\operatorname{cough}^{5}$. It's anti-asthmatic ${ }^{6}$ and anti-cancer activities were already proved. A review of literature afforded no information on the hepatoprotective aspects of this plant. So the present study is therefore an attempt to assess the efficacy of this indigenous herb for its hepatoprotective activity against mercury induced toxicity model in mice.

\section{MATERIALS AND METHODS}

\section{Plant material}

The aerial parts of the plant were collected from the foothill of Yercaud, Salem, in the month of June 2011 and cleaned to remove the debris. The collected plant was identified and authenticated by a botanist. A voucher specimen (SOTK-1) has been kept in our museum for future reference. The plant parts were dried at room temperature for $10 \mathrm{~d}$ and coarsely powdered with the help of a hand-grinding mill and the powder was passed through sieve No. 60.

\section{Preparation of the extract ${ }^{8}$}

The powder of aerial parts of $S$. trilobatum was extracted separately by continuous hot extraction process using soxhlet apparatus with different solvents in increasing order of polarity from petroleum ether, chloroform, acetone, alcohol, to finally chloroform:water. After extraction, the extracts were concentrated under reduced pressure in tared vessel. The marc of crude drug powder was then once again subjected to successive extraction with other solvents and the extractive values were calculated with reference to the air-dried drug. The dry extracts were subjected to various chemical tests to detect the presence of different phytoconstituents.

\section{Test animals}

Swiss albino mice of either sex and of approximately the same age, weighing about 20-25 g were used for the study. They were housed in polypropylene cages and fed with standard chow diet and water ad libitum. The animals were exposed to alternate cycle of $12 \mathrm{~h}$ of darkness and light each. Before each test, the animals were fasted for 
atleast $12 \mathrm{~h}$. The experimental protocols were subjected to the scrutinization of the Institutional Animal Ethics Committee and were cleared by the same.

\section{Hepatoprotective study}

For determining the hepatoprotective activity animals were divided into four groups containing 6 animals each. Group I served as control and received orally $1 \mathrm{ml}$ of propylene glycol daily for 7 consecutive days. Group II was treated with chloroform extract of S. trilobatum (300 $\mathrm{mg} / \mathrm{kg}$, p.o.) for 7 days. Group III was served as positive control and received Mercuric chloride $(5 \mathrm{mg} / \mathrm{kg}$ ) in normal saline through i.p. for 7 days $^{9}$. Group IV was treated with chloroform extract of $S$. trilobatum (300 $\mathrm{mg} / \mathrm{kg}$, p.o.), before mercuric chloride administration and until 7 days of mercuric chloride administration. The animals were autopsied at $7^{\text {th }}$ day after mercuric chloride administration. The liver was excised and processed for $\mathrm{GSH}^{10}$ and $\mathrm{LPO}^{11}$ estimation. Blood from autopsied animals were collected by cardiac puncture and the biochemical parameters such as $\mathrm{ALT}^{12}, \mathrm{AST}^{13}$ and $\mathrm{ALP}^{14}$ were estimated as reported earlier. A small portion of liver was cut from the animals from each group and preserved in neutral buffered formalin and was processed for paraffin embedding, following the standard microtechnique ${ }^{15} .5 \mu$ section of the livers stained with alum haemotoxylin and eosin and studied for degenerative and necrotic changes.

\section{Statistical analysis}

All values were expressed as mean \pm SEM. The data were statistically analyzed using one way ANOVA followed by Newman Keul's multiple range test and differences below $\mathrm{P}<0.05$ are considered as significant.

\section{RESULTS}

The plant $S$. trilobatum was collected from the foothill of Yercaud, Salem, air-dried and extracted by continuous hot extraction process using soxhlet apparatus. The average percentage yield of chloroform extract of $S$. trilobatum was found to be $3.2 \% \mathrm{w} / \mathrm{w}$. The $\mathrm{LD}_{50}$ was found to be $2893 \mathrm{mg} / \mathrm{kg}$ for chloroform extract of S. trilobatum.

The chloroform extract did not exhibit and toxic effects up to $1000 \mathrm{mg} / \mathrm{kg}$ when administered to mice as a single i.p. dose. The results of biochemical parameters revealed to the elevation of enzyme level in mercury chloride treated group indicating that mercury induces damage to the liver. Mercuric chloride induces pathological changes in the liver such as cytoplasmic vacuolization, karyohexsis, karyolysis, pycnosis and centrilobular necrosis. However, in group IV reduced cytoplasmic vacuolization and centrilobular necrosis were observed. Animals treated with chloroform extract of $S$. trilobatum before and after mercury intoxication showed a significant decrease in LPO level, AST and ALT activities and increase in ALP activity and GSH content (Table 1). The enzyme levels were almost restored to the normal. So the animals treated with chloroform extract of $S$. trilobatum exhibited statistically significant $(\mathrm{P}<0.05)$ protection against mercury-induced hepatotoxicity in mice, which is comparable to the control. The histopathological studies support the biochemical findings. Hepatotoxicity induced by mercury manifested itself by the $7^{\text {th }} \mathrm{d}$ with the liver showing massive degeneration enveloping the not so visible necrotic areas as compared to the normal.

Table 1: Effect of chloroform extract of S. trilobatum on Mercury induced hepatotoxicity in mice

\begin{tabular}{|l|c|c|c|c|c|c|}
\hline \multicolumn{1}{|c|}{ Treatment } & $\begin{array}{c}\text { Dose } \\
\mathrm{mg} / \mathrm{kg}, \mathrm{p} . \mathrm{o} .\end{array}$ & $\begin{array}{c}\mathrm{AST} \\
\mathrm{U} / \mathrm{ml}\end{array}$ & $\begin{array}{c}\text { ALT } \\
\mathrm{U} / \mathrm{ml}\end{array}$ & $\begin{array}{c}\text { ALP } \\
\text { KAU }\end{array}$ & $\begin{array}{c}\text { GSH } \\
\mu \text { mole/g }\end{array}$ & $\begin{array}{c}\text { LPO content } \mathrm{n} \\
\text { mole of MDA/mg }\end{array}$ \\
\hline Control & $1 \mathrm{ml}$ & $21.50 \pm 1.55$ & $14.33 \pm 0.82$ & $6.10 \pm 0.05$ & $95.33 \pm 1.79$ & $4.62 \pm 0.03$ \\
\hline S. trilobatum & 300 & $21.67 \pm 1.14$ & $13.17 \pm 0.90$ & $6.33 \pm 0.02$ & $99.50 \pm 1.22$ & $3.83 \pm 0.12$ \\
\hline Mercuric chloride & 5 & $52.50 \pm 1.22$ & $46.83 \pm 0.57$ & $2.77 \pm 0.10$ & $42.83 \pm 0.90$ & $17.33 \pm 0.33$ \\
\hline $\begin{array}{l}\text { S. } \text { trilobatum }+ \\
\text { Mercuric chloride }\end{array}$ & 300 & $24.67 \pm 1.63^{*}$ & $23.67 \pm 1.63^{*}$ & $4.62 \pm 0.03^{*}$ & $69.67 \pm 0.49^{*}$ & $7.93 \pm 0.06^{*}$ \\
\hline
\end{tabular}

$* P<0.05$ when compared with control. Number of individuals used $=6$ in each group. Days of drug treatment $=7$. Values are expressed as mean \pm S.E.M

\section{DISCUSSION}

Mercury intoxication showed a significant increase in ALT and AST levels. The increase in ALT and AST in serum may be due to hepatocellular necrosis, which causes increase in permeability of the cell membrane resulting in the release of transaminases in the blood stream $^{16,17}$. Further, there was a decrease in the serum alkaline phosphatase activity after mercuric chloride intoxication. In the liver it is closely connected with lipid membrane in the canalicular zone, so that any interference with the bile flow, whether extra hepatic or intra hepatic leads to decrease in serum alkaline phosphatase activity ${ }^{17}$. Mercury causes cell membrane damage (lipid peroxidation), which leads to the imbalance between synthesis and degradation of enzyme protein ${ }^{18}$, thus lowering the enzyme activity. Present findings are in agreement with the findings of El-Demerdash ${ }^{19}$, who showed that mercuric chloride $(0.5 \mu \mathrm{mol} / \mathrm{ml})$ intoxication significantly decreases the alkaline phosphatase activity in rats.

GSH is a major thimol, which binds electrophilic molecular species and free radical intermediates. It plays a central role in the antioxidant defence system, metabolism and detoxification of exogenous and endogenous substances ${ }^{20,21}$. Mercury has high affinity for GSH and causes the irreversible excretion of up to two GSH tripeptides $^{22}$. The metal-GSH conjugation process is desirable in that it results in the excretion of the toxic metal in to the bile. However, mercury can deplete the GSH from the cell and decrease the antioxidant potential. In the present investigation it was observed that mercuric chloride treatment significantly reduced the GSH content 
Ekambaram et al

Journal of Drug Delivery \& Therapeutics; 2012, 2(6), 68-70

thus reducing the antioxidant potential and accelerating the lipid peroxidation, resulting in cellular damage. The efficacy of any hepatoprotective drug is dependent on its capacity of either reducing the harmful effect or maintaining the normal hepatic physiology, which has been disturbed by a hepatotoxin. The extracts decreased mercury induced elevated levels of the enzymes in group IV, indicates the production of structural integrity of hepatocytic cell membrane or regeneration of damaged liver cells by the extracts.

\section{REFERENCES}

1. Miller OM, Lund BO, Woods JS, Reactivity of Hg (II) with superoxiode: Evidence for the catalytic dismutation of superoxide by Hg (II). J Biochem Toxicol, 1991, 6, 293-295.

2. Halliwell B, Gutteridge JMC. Lipid peroxidation-A radical Chain reaction in free radicals in biology and medicine, Oxford, UK (Clarendon press), 1989, p. 58-63.

3. Hussain S, Alkinson A, Thomson SJ, Khan AT, Accumulation of mercury and its effect on antioxidant enzymes in brain, liver and kidneys of brain. J Environ Sci Health B, 1999, 34, 645648.

4. Benov LC, Benchev IC, Monovich OH, Thiol antidotes effect on lipid peroxidation in mercury poisoned rats. Chem Biol Interact., 1990, 76, 321-324.

5. Kirtikar KR, Basu BD. Indian Medicinal Plants, $2^{\text {nd }}$ Edn., Vol. III, Bishen Singh Mahendrapal Singh Dehradun, 1993, p.176263.

6. Govindan S, Viswanathan S, Vijayasekaran V, Alagappan R, A pilot study on the clinical efficacy of Solanum xanthocarpum and Solanum trilobatum in bronchial asthma. J Ethnopharmacol., 1999, 66, 205-10.

7. Mohanan PV, Devi KS, Cytotoxic potential of the preparations from Solanum trilobatum and the effect of sobatum on tumour reduction in mice. Cancer Lett., 1999, 110: 71-76.

8. Kokate CK. Practical Pharmacognosy, 3rd Edn., Vallabh Prakashan, New Delhi, 1994. p.107-109.

9. Mukesh Kumar S, Madhu K, Ashok K, Ocimum santum aqueous leaf extract provides protection against mercury induced toxicity in Swiss albino mice. Indian J Exp Biol., 2002, 40, 1079-1082.

10. Moron MJ, Depierre JW, Mannlrvik B, Levels of GSH, GR, and GST activities in rat lungs and liver. Biochem Biophys Acta, 1979, 582, 67-69.
So, the result of present investigation indicates that the chloroform extract of $S$. trilobatum possess good hepatoprotective activity. Further investigations are required to characterize the active hepatoprotective principle and its mechanism of action.

\section{ACKNOWLEDGEMENT}

We thank Dr. B. Jayakar, Principal, Vinayaka Mission's College of Pharmacy, Salem, for his encouragement and support throughout the work.

11. Okhawa H, Ohishi N, Yagi K, Assay for lipid peroxidation in animal tissue by thio barbituric acid reaction. Analyt Biochem, 1979, 95, 351-355.

12. Reitman S, Frankel SA, A colorimetric method for the determination of serum glutamate oxaloacetic acid and glutamic pyruvate transaminases. Am J Cl Path 1957, 28, 5663.

13. Armilage P, Berry G. Statistical methods of Medical Research, II ed., Blackwell Scientific Publications, Oxford, 1985, p.186192.

14. Kind PRN, King EJ, Determination of serum alkaline phosphatase. Clin Path 1954, 7, 322-326.

15. Galigher AE, Kozloff EN. Essential Practical Microtechnique, $2^{\text {nd }}$ Edn., Lea and Febiger, Philadelphia, 1971, p.197-210.

16. Rana SVS, Singh R, Verma S, Protective effects of few antioxidants on liver function in rats treated with cadmium and mercury. Indian J Exp Biol, 1996, 34, 177-179.

17. Vandenberghe J. Hepatotoxicology: Mechanisms of liver toxicity and methodological aspects in toxicology-Principles and applications, CRC Press, 1995, p.718-722.

18. Hardonk MJ, Koudstaal J. Enzyme histochemistry as a link between biochemistry and morphology, Gustav Fischer, Stuttgart, 1976, p.40-44.

19. El-Demerdash FM, Effects of selenium and mercury on the enzymatic activities and lipid peroxidation in brain, liver and blood of rats. J Environ Sci Health B 2001, 36, 489-491.

20. Ketterer B, Coles B, Meyer DJ. The role of glutathione in detoxication. Environ Health Perspect, 1983, 49, 59-62.

21. Meister A, Andersen ME. Glutathione. Ann Rev Biochem., 1983, 52, 711-715.

22. Zalups RK, Lash LH, Interactions between glutathione and mercury in the kidney, liver and blood. In: Toxicology of metal, edited by LW Chang, CRC Press, Boca Raton, 1996, p. 145-156. 